\title{
PERUBAHAN STATUS GIZI BALITA DENGAN AKUPRESUR SELAMA PEMBERIAN MAKANAN TAMBAHAN (PMT) PEMULIHAN PADA BALITA
}

\author{
Enggar Anggraeni ${ }^{1}$, Mirthasari Palupi ${ }^{2}$ dan Risma Trisnagati ${ }^{3}$ \\ ${ }^{1-3}$ Akademi Gizi Karya Husada Kediri, Indonesia \\ Jl. Soekarno Hatta No.7, Sambirejo, Kec. Pare, Kabupaten Kediri \\ Telp./Fax. (0354) 394909 \\ Email : eeng.gizi@gmail.com ${ }^{1}$; mirthasaripalupi@gmail.com ${ }^{2}$
}

\begin{tabular}{l} 
Article Info \\
\hline Article history: \\
Received July $14^{\text {th }}, 2020$ \\
Revised August $21^{\text {th }}, 2020$ \\
Accepte September $25^{\text {th }}, 2020$ \\
\hline Keyword: \\
Acupressure; Recovery \\
Supplementary Food (PMT \\
Recovery); The Nutritional \\
Status
\end{tabular}

\section{Kata Kunci :}

Akupresur; Balita; Status Gizi; PMT

\begin{abstract}
Background : Nutritional problems are still one of the problems faced by Indonesia. Malnutrition and micronutrient deficiencies are major nutritional problems facing Indonesia. Macro-nutrient deficiency occurs when the body lacks energy and protein, this is due to a gap between nutritional needs and nutrient intake so that it can cause a deficiency of micronutrients in the body which has an impact on malnutrition or malnutrition status. Inadequate nutrition is a condition of a lack of energy and protein intake, while malnutrition is a lack of energy and protein intake for a long period of time. Provision of Recovery Supplement (PMT Recovery) is a program aimed at overcoming the problem of malnutrition and malnutrition by improving nutritional status, fulfilling children's nutritional needs so that good nutritional status and condition are achieved according to the child's age. So that in this study the role of PMT is used in order to increase body weight and nutritional status of children.
\end{abstract}

Objectives : The purpose of this study was to distinguish nutritional status during supplementation with supplementary food with acupressure.

Methods : This research uses quantitative research type, with the research design used is Quasy Experiment with Pre and Post Test Control Group Design approach. The statistical test used was the Independent t-Test and Wilcoxon test.

Results : The results of the study conducted on 3 - 16 July 2020 with a sample of 10 toddlers with acupressure, weight gain before and after PMT administration ranged from 0.2 to $0.4 \mathrm{~kg}$, while the $p$ value is $0.004<0.05$ then there are the difference between body weight before and after giving PMT. As for the Nutritional Status of the statistical test results obtained p value of 0.083 (> 0.05) which indicates that there is no difference between the nutritional status of children under five before and after giving PMT.

\footnotetext{
ABSTRAK

Latar Belakang : Permasalahan gizi masih menjadi salah satu masalah yang dihadapi oleh Indonesia. Kekurangan gizi makro dan kekurangan gizi mikro merupakan masalah gizi utama yang dihadapi Indonesia. Kekurangan zat gizi makro terjadi apabila tubuh kekurangan energi dan protein, hal ini dikarenakan adanya kesenjangan antara kebutuhan zat gizi dan asupan zat gizi sehingga dapat menyebabkan terjadinya kekurangan zat gizi mikro dalam tubuh yang berdampak pada status gizi kurang atau gizi buruk. Gizi kurang merupakan keadaan kurangnya pemasukan energi dan
} 
protein sementara gizi buruk merupakan kurangnya pemasukan energi dan protein dalam jangka waktu yang cukup lama. Pemberian Makanan Tambahan Pemulihan (PMT Pemulihan) adalah program yang ditujukan untuk mengatasi masalah gizi kurang dan gizi buruk dengan meningkatkan status gizi, mencukupi kebutuhan zat gizi anak sehingga tercapai status gizi dan kondisi yang baik sesuai dengan usia anak. Sehingga dalam penelitian ini peran PMT digunakan agar dapat meningkatkan berat badan dan status gizi balita.

Tujuan : Tujuan dari penelitian ini adalah Untuk membedakan status gizi selama pemberian makanan tambahan pada balita dengan akupresur.

Metode : Penelitian ini menggunakan jenis penelitian kuantitatif, dengan rancangan penelitian yang digunakan adalah Quasy Experiment dengan pendekatan Pre and Post Test Control Group Design. Uji statistik yang digunakan adalah uji Independent $t$-Test dan Wilcoxon.

Hasil : Hasil penelitian yang telah dilakukan pada tanggal 3 - 16 Juli 2020 dengan sampel 10 balita dengan akupresur, kenaikan berat badan sebelum dan sesudah pemberian PMT berkisar antara 0,2-0,4 $\mathrm{Kg}$, sementara nilai $p$ value yaitu 0,004 < 0,05 maka terdapat perbedaan antara berat badan sebelum dan sesudah pemberian PMT. Sedangkan untuk Status Gizi hasil uji statistik didapatkan nilai p value sebesar 0,083 (>0,05) yang menunjukkan bahwa tidak ada perbedaan antara status gizi balita sebelum dan sesudah pemberian PMT.

Copyright $\odot$ Jurnal Gizi Prima All rights reserved.

\section{PENDAHULUAN}

Kekurangan gizi makro dan kekurangan gizi mikro merupakan masalah gizi utama yang sering terjadi di berbagai negara berkembang. Masalah utama gizi ini masih menjadi permasalahan yang dihadapi Indonesia. Kekurangan zat gizi makro terjadi apabila tubuh kekurangan energi dan protein, hal ini dikarenakan adanya adanya kesenjangan antara kebutuhan zat gizi dan asupan zat gizi sehingga juga dapat menyebabkan terjadinya kekurangan zat gizi mikro dalam tubuh (Depkes RI, 2002). Kekurangan zat gizi makro maupun mikro dalam waktu yang lama dapat mengakibatkan seseorang mengalami gizi kurang atau gizi buruk. Gizi kurang merupakan keadaan kurangnya pemasukan energi dan protein dalam jangka waktu yang cukup lama sehingga dapat menimbulkan dampak yang sulit disembuhkan bagi tubuh dan menghambat perkembangan seseorang (Suhardjo, 2003). Kekurangan gizi menurut Almatsier (2004) merupakan penyakit yang terjadi sebagai dampak kekurangan makanan sumber energi dan kekurangan makanan sumber protein, sementara gizi buruk merupakan ketidaksesuaian konsumsi zat gizi dalam makanan apabila dibandingkan dengan Angka Kecukupan Gizi (AKG) yang seharusnya serta akan diikuti dengan adanya kekurangan beberapa zat gizi lainnya.

Pemantauan Status Gizi (PSG) Indonesia pada tahun 2013 menunjukkan persentase balita kurang gizi sebanyak 13,9\% dan persentase balita gizi buruk sebanyak 5,7\%. Pada tahun 2018 terdapat penurunan prevalensi balita yang memiliki status gizi kurang sebesar $0,1 \%$ yaitu $13,8 \%$ dan penurunan prevalensi balita gizi buruk sebesar 1,8\% yaitu 3,9\% (Riskesdas, 2018). Angka ini merupakan salah satu indikator bahwa Indonesia termasuk negara dengan kategori gizi akut $(>5 \%)$.

Terdapat beberapa masalah gizi yang banyak dijumpai pada balita selain terjadinya KEP yaitu stunting, kurangnya vitamin A, anemia gizi besi, dan kegemukan. Susilowati menyatakan bahwa hal ini bergantung pada pemenuhan nutrisi untuk pertumbuhan dan perkembangan anak. Kurangnya mengkonsumsi sayuran dan buah yang berwarna dapat menyebabkan balita mengalami kekurangan vitamin A. Adanya kesulitan makan pada balita yang dapat menyebabkan munculnya berbagai gangguan dalam pertumbuhan maupun perkembangan pada anak seperti penurunan daya tahan tubuh, adanya gangguan saat tidur, adanya gangguan 
pada kesimbangan dan koordinasi, perubahan anak menjadi agresif, impulsif, kesulitan buang air besar, karies gigi serta pica.

Kesulitan makan dapat diatasi dengan menggunakan dua cara yaitu dengan cara pemberian obat (farmakologi) maupun tanpa pemberian obat (non-farmakologi). Wong (2011) menyatakan bahwa upaya dengan farmakologi dapat diberikan melalui multivitamin, dan micronutrien lainnya, sementara upaya non farmakologi diberikan melalui minuman herbal seperti jamu, pijat, akupresur, dan akupunktur.

Akupresur merupakan salah satu upaya non farmakologi yang merupakan perawatan tradisional dengan menggunakan keterampilan yang dilakukan dengan teknik penekanan di titik-titik akupuntur tertentu yang ada pada permukaan tubuh dengan menggunakan jari atau alat bantu tumpul yang memiliki tujuan untuk perawatan kesehatan (Kemenkes RI, 2017). Akupresur adalah upaya non farmakologi yang sudah ada cukup lama, namun penggunaan nya sangat jarang dalam memberika asuhan pada balita. Di masyarakat umumnya anak hanya mendapat pijat saat baru lahir sampai usia 40 hari atau apabila terdapat masalah otot pada anak (Shoim, 2006).

Penelitian ini bertujuan untuk membedakan status gizi selama pemberian makanan tambahan pada balitadengan akupresur di Desa Sitimerto Kecamatan Pagu Kabupaten Kediri.

\section{METODE PENELITIAN}

Penelitian ini merupakan jenis penelitian kuantitatif yang menggunakan Quasy Experiment sebagai rancangan penelitian dengan pendekatan pre and post test control group design. Penelitian ini menggunakan uji independent t-Test dan Wilcoxon sebagai uji statistik. Populasi dari penelitian ini adalah semua balita yang ada di Desa Sitimerto Kecamatan Pagu Kabupaten Kediri, sedangkan sampel adalah balita kurus, balita 2T (berat badan tidak naik 2 kali secara berturut-turut) dan balita Bawah Garis Merah (BGM) sejumlah 10 Balita. Sepuluh (10) balita yang menjadi sampel akan di recall 24 jam terlebih dahulu kemudian diberikan PMT Pemulihan selama 14 hari dan dilakukan akupresur selama 4 kali.

\section{HASIL PENELITIAN}

\section{Karakteristik Responden}

Hasil penelitian menunjukkan karakteristik 10 orang responden. Karakteristik balita diperoleh melalui hasil wawancara dengan bantuan form identitas responden. Karakteristik responden dapat dilihat pada tabel 1.

Tabel 1. Distribusi Frekuensi Karakteristik Responden

\begin{tabular}{|c|c|c|}
\hline Karakteristik Balita & $\mathbf{n}$ & $\%$ \\
\hline \multicolumn{3}{|l|}{ Usia : } \\
\hline 1 Tahun & 3 & 30 \\
\hline 3 Tahun & 5 & 50 \\
\hline 4 Tahun & 2 & 20 \\
\hline Jumlah & 10 & 100 \\
\hline \multicolumn{3}{|l|}{ Jenis Kelamin : } \\
\hline Laki-Laki & 6 & 60 \\
\hline Perempuan & 4 & 40 \\
\hline Jumlah & 10 & 100 \\
\hline \multicolumn{3}{|l|}{ Status Gizi : } \\
\hline Gizi Baik & 0 & 0 \\
\hline Gizi Kurang & 10 & 100 \\
\hline Jumlah & 10 & 100 \\
\hline
\end{tabular}

Sumber : Data primer 2020

Berdasarkan tabel distribusi frekuensi karakteristik responden diketahui rata-rata usia balita yaitu 3 tahun yaitu sebanyak 5 orang (50\%). Karakteristik balita berdasarkan dari jenis kelamin yaitu sebanyak 6 orang $(60 \%)$ balita laki-laki. Status gizi semua balita masih dalam kurang gizi (100\%). 


\section{Perubahan Berat Badan}

Tabel 2. Distribusi Berat Badan Sebelum dan Sesudah PMT

\begin{tabular}{ccc}
\hline & Berat Badan & p-value \\
\hline Sebelum & Sesudah & 13 \\
7,5 & 7,8 & \\
9 & 9,3 & \\
10,5 & 10,9 & 0,004 \\
11,4 & 11,6 & \\
13,4 & 13,6 & \\
10,8 & 11 & \\
10,3 & 10,6 & \\
12,9 & 13,1 & \\
11,4 & 11,6 & \\
\hline
\end{tabular}

\section{Perubahan Status Gizi}

Tabel 3. Distribusi Status Gizi Berdasarkan indeks BB/U sebelum dan sesudah PMT

\begin{tabular}{|c|c|c|c|c|c|}
\hline \multirow{2}{*}{ Status Gizi } & \multicolumn{2}{|c|}{ Sebelum } & \multicolumn{2}{|c|}{ Sesudah } & \multirow{2}{*}{ p-value } \\
\hline & $\mathbf{n}$ & $\%$ & $\mathbf{n}$ & $\%$ & \\
\hline Gizi Baik & 0 & 0 & 3 & 30 & \\
\hline Gizi Kurang & 10 & 100 & 7 & 70 & 0,083 \\
\hline Jumlah & 10 & 100 & 10 & 100 & \\
\hline
\end{tabular}

\section{PEMBAHASAN}

Karakteristik Responden

\section{Karakteristk Berdasarkan Usia Balita}

Balita adalah kelompok anak yang ada pada usia 1-3 tahun atau batita (bayi tiga tahun) dan kelompok anak yang ada pada usia 3-5 tahun atau anak prasekolah (Sutomo dan Anggraeni, 2010). Muaris (2006) menyatakan bahwa usia balita merupakan usia yang ada pada tahap pertumbuhan bagi anak, sehingga pada usia ini anak membutuhkan konsumsi zat gizi yang setara dengan kebutuhannya. Kebutuhan zat gizi pada balita akan meningkat seiring dengan bertambahnya usia (Arifin, 2015). Hasil penelitian yang dilakukan menunjukkan usia anak balita rata-rata terdapat pada usia 3 tahun yaitu sebesar 5 responden (50\%). Pada usia 25- 36 bulan aktivitas balita akan mengalami peningkatan sehingga terjadi peralihan makanan yang dikonsumsi seiring dengan bertambahnya usia. Pertumbuhan dan perkembangan pada masa balita berjalan dengan sangat cepat, sehingga pemenuhan akan kebutuhan zat gizi harus mempertimbangkan aktivitas dan keadaan infeksi balita (Kemenkes, 2014). Penelitian yang dilakukan ini sesuai dengan yang dilakukan Sumiati (2007) yaitu anak usia 13-36 sebagian besar menderita KEP, hal ini dikarenakan pada usia ini balita lebih mudah terserang berbagai macam penyakit selain itu pada usia ini anak sudah dapat memilih sendiri makanan yang ingin dikonsumsi (konsumen aktif).

\section{Karakteristik Berdasrkan Jenis Kelamin Balita}

Jenis kelamin berhubungan dengan kebutuhan energi dan zat gizi balita sehingga jenis kelamin juga dapat mempengaruhi status gizi balita. Almatsier (2009) manyatakan bahwa anak laki-laki membutuhkan energi lebih besar daripada perempuan, hal ini juga mengakibatkan anak laki-laki memiliki peluang yang lebih besar untuk menderita KEP apabila dibandingkan dengan perempuan jika kebutuhan nya tidak terpenuhi dengan baik. Hasil penelitian menunjukkan persentase laki-laki lebih banyak dibandingkan perempuan yaitu sebanyak 6 balita (60\%). Penelitian yang dilakukan oleh Setyaningsih (2008) menyatakan bahwa penderita gizi buruk di dominasi oleh anak laki-laki dengan persentase sebesar 54,84\% dan di dukung dengan laporan mengenai jumlah keseluruhan gizi buruk balita yang dilihat menurut jenis kelamin yaitu dari $12 \%$ balita gizi buruk 6,3\% adalah laki-laki (Depkes, 2010). 


\section{Karakteristik Berdasarkan Status Gizi Balita}

Indikator untuk mengetahui keadaan gizi seseorang yang dapat diketahui melalui indeks berat badan menurut usia disebut status gizi. Status gizi juga dapat diartikan sebagai kondisi tubuh seseorang yang dilihat melalui konsumsi makanan serta penggunaan zat gizi dalam tubuh setiap orang (Almatsier, 2005). Terdapat beberapa faktor yang mempengaruhi status gizi seseorang antara lain yaitu usia anak dan orang tua, pekerjaan dan tingkat pendidikan orang tua, jenis kelamin, jumlah keluarga, lama anak menyusu dan konsumsi makanan anak. Penelitian ini sejalan dengan penelitian Gusti (2010) dimana konsumsi makanan yang diterima balita dapat mempengatuhi keadaan status gizi balita.

\section{Perubahan Berat Badan}

Perubahan berat badan baik peningkatan maupun penurunan berat badan dapat mengakibatkan perubahan pada status gizi anak. Perubahan berat badan di dapatkan melalui kesenjangan berat badan akhir dengan berat badan awal. Kenaikan berat badan pada balita secara umum berkisar antara 0,2-0,4 Kg. Pengadaan PMT bagi anak dapat digunakan sebagai upaya dalam mengatasi kekurangan gizi pada usia balita. PMT ini hanya digunakan sebagai selingan dari makanan yang dikonsumsi sehari-hari. PMT yang digunakan akan lebih baik apabila menggunakan bahan makanan lokal yang ada di sekitar daerah yang mudah ditemui di daerah tempat tinggal balita. Berdasarkan tabel 2 diketahui terjadi peningkatan berat badan pada balita sebelum dan sesudah PMT berkisar antara 0,2-0,4 kg dengan nilai $\mathrm{p}$ value $0,004<0,05$ sehingga adanya perbedaan antara berat badan sebelum dan sesudah PMT. Anditia, dkk (2012) mengungkapkan pemberian PMT baik untuk berat badan balita dengan nilai $\mathrm{p}$ value $0,000(\mathrm{p}<0,05)$. Evida juga mengungkapkan hal yang sama, dimana terdapat perbedaan berat badan sebelum dan sesudah PMT dan PMT untuk balita di Wilayah Puskesmas Sei Tatas memiliki pengaruh yang signifikan terhadap status gizi dengan nilai signifikansi sebesar 0,000 (p $<0,05)$.

\section{Perubahan Status Gizi}

Tabel 3 menunjukkan terdapat 3 responden (30\%) yang mengalami perbaikan status gizi yaitu terjadi perubahan dari kurang menjadi baik. Responden yang tidak mengalami perubahan status gizi terdapat 7 responden $(70 \%)$. Terdapat beberapa faktor lain yang mempengaruhi status gizi pada balita yang tidak mendapati perubahan status gizi dan dijadikan variabel. Faktor tersebut adalah seperti wawasan ibu, ketersediaan pangan, keadaan sosial dan ekonomi dan wawasan ibu mengenai gizi dan kesehatan. Khamson, A (2008) menyatakan hal yang sejalan dengan hasil penelitian yang dilakukan dimana kemiskinan merupakan penyebab masalah gizi sehingga akses untuk mendapatkan pangan anak menjadi terganggu, selain kemiskinan penyebab lain yang dapat mempengaruhi adalah ketidaktahuan orang tua yang dapat disebabkan karena kurangnya pendidikan sehingga mengakibatkan rendahnya wawasan yang dimiliki dan memunculkan perilaku tidak suka pada makanan. Ketidaktahuan mengenai gizi mengakibatkan kesalahan dalam pemilihan bahan makanan dan cara pengolahannya. Akan tetapi orang tua dengan wawasan gizi yang baik akan mempraktekan pola makan sehat bagi anak-anaknya sehingga kebutuhan gizi nya terpenuhi. Almatsier (2010) juga menyatakan bahwa kemiskinan, ketidaksediaan pangan, lingkungan yang kurang baik, pengetahuan masyarakat mengenai gizi yang rendah, menu seimbang dan kesehatan merupakan penyebab umum terjadinya gizi kurang pada anak. Dari pengujian statistik didapatkan nilai p value sebesar 0,083 $(>0,05)$ dimana tidak ada perbedaan antara status gizi balita dengan akupresur sebelum dan sesudah pemberian PMT.

\section{KESIMPULAN}

Sepuluh (10) balita dengan akupresur, peningkatan berat badan sebelum dan sesudah pemberian PMT antara 0,2-0,4 Kg dengan nilai $\mathrm{p}$ value $0,004<0,05$ sehingga terdapat perbedaan antara berat badan sebelum dan sesudah pemberian PMT. Hasil pengujian statistik status gizi mendapatkan nilai p value sebesar 0,083 $(>0,05)$ sehingga tidak ada perbedaan antara status gizi balita sebelum dan sesudah pemberian PMT.

\section{SARAN}

Untuk penelitian selanjutnya disarankan untuk menambahkan waktu penelitian agar dapat terlihat hasil yang lebih maksimal.

\section{DAFTAR PUSTAKA}

Almatsier, S. (2004). Prinsip Dasar Ilmu Gizi. Jakarta : Gramedia Pustaka Utama

Almatsier, S. (2005). Perinsip Dasar Ilmu Gizi, Jakarta : PT. Gramedia Utama. 
Almatsier, S. (2009). Perinsip Dasar Ilmu Gizi Cetakan Ke VII Jakarta : PT Gramedia Utama.

Almatsier, S. (2010). Perinsip Dasar Ilmu Gizi, Jakarta : PT Gramedia Utama.

Anditia E, Suryandari A, Dan Walin. (2012). Efektivitas Program PMT Pemulihan Terhadap Kenaikan Berat Badan Pada Balita Status Gizi Buruk Di Kabupaten Banyumas. Purwokerto.

Arifin, Z. (2015). Gambaran Pola Makan Anak Usia 3-5 Tahun Dengan Gizi Kurang Di Pondok Bersalin Tri Sakti Balong Tani Kecamatan Jabon-Sidoarjo.

Departemen Kesehatan RI. Laporan Riskesdas (2010). Badan Penelitian Dan Pengembangan Kesehatan Republik Indonesia. Jakarta.

Depkes RI. (2002). Program Gizi Makro. Jakarta.

Gusti AKM. (2010). Hubungan Perilaku Ibu Dalam Pemberian Gizi Seimbang Dengan Status Gizi Pada Balita Di Posyandu Kelurahan Depok Kecamatan Pancoran Mas Kota Depok (Skripsi). Jakarta: Fakultas Ilmu Kesehatan, Universitas Pembangunan Nasional Veteran.

Kementerian Kesehatan RI. (2014). Pedoman Gizi Seimbang. Riskesdas.

Muaris, H. (2006). Lauk Bergizi Untuk Anak Balita. Jakarta: PT. Gramedia

Setyaningsih, P. (2008). Pengaruh Kompetensi Bidan Di Desa Dalam Manajemen Kasus Gizi Buruk Anak Balita Terhadap Pemulihan Kasus Di Kabupaten Pekalongan Tahun 2008. Semarang: Universitas Diponegoro

Suhardjo. (2003). Berbagai Cara Pendidikan Gizi. Jakarta : BUMI AKSARA

Sumiati, I. (2007). Evaluasi Penatalaksanaan Asuhan Gizi (Nutrition Care) Pada Balita Kurang Energi Protein (KEP) Di RSUD Ulin Banjarmasin. Malang: Universitas Brawijaya.

Sutomo B dan Anggraini D. (2010). Menu Sehat Alami Untuk Batita Dan Balita. Jakarta: Demedia. 